University of Nebraska - Lincoln

DigitalCommons@University of Nebraska - Lincoln

Faculty Papers and Publications in Animal

Science

Animal Science Department

$1-9-2008$

\title{
Utilization of soybeans or corn milling by-products in beef heifer development diets
}

\author{
H. L. Harris \\ University of Nebraska-Lincoln \\ Andrea S. Cupp \\ University of Nebraska-Lincoln, acupp2@unl.edu
}

\author{
A. J. Roberts \\ USDA, ARS, Fort Keogh Livestock and Range Research Laboratory, Miles City, MT, \\ andy.roberts@ars.usda.gov \\ Richard N. Funston \\ University of Nebraska-Lincoln, rfunston2@unl.edu
}

Follow this and additional works at: https://digitalcommons.unl.edu/animalscifacpub

Part of the Animal Sciences Commons

Harris, H. L.; Cupp, Andrea S.; Roberts, A. J.; and Funston, Richard N., "Utilization of soybeans or corn milling by-products in beef heifer development diets" (2008). Faculty Papers and Publications in Animal Science. 168.

https://digitalcommons.unl.edu/animalscifacpub/168

This Article is brought to you for free and open access by the Animal Science Department at DigitalCommons@University of Nebraska - Lincoln. It has been accepted for inclusion in Faculty Papers and Publications in Animal Science by an authorized administrator of DigitalCommons@University of Nebraska - Lincoln. 


\title{
Utilization of soybeans or corn milling by-products in beef heifer development diets ${ }^{1,2}$
}

\author{
H. L. Harris, ${ }^{*}$ A. S. Cupp, $\dagger$ A. J. Roberts, + and R. N. Funston*3 \\ *University of Nebraska, West Central Research and Extension Center, North Platte 69101; \\ $\dagger$ Department of Animal Science, University of Nebraska-Lincoln 68583; and $\ddagger U S D A$, ARS, \\ Fort Keogh Livestock and Range Research Laboratory, Miles City, MT 59301
}

\begin{abstract}
Whole raw soybeans (SB), wet corn gluten feed (WCGF), and corn dried distillers grains (DDG) are sources of protein in heifer development rations. The objectives of this study were to compare puberty status before synchronization of estrus, response to synchronization, and $\mathrm{AI}$ and final pregnancy rates in heifers developed on diets containing SB, WCGF, or DDG that were formulated to be similar in energy and CP. These ingredients vary substantially in fat content, which may affect reproductive performance. Rate of gain during the feeding period and post-AI performance were also compared. In a preliminary experiment, 104 crossbred heifers were fed diets containing either 1.25 $\mathrm{kg}$ of SB/d or $2.0 \mathrm{~kg}$ of WCGF/d for $110 \mathrm{~d}$ (DM basis), beginning at 10 mo of age. In Exp. 1, 100 crossbred heifers received either $1.25 \mathrm{~kg}$ of $\mathrm{SB} / \mathrm{d}$ or $2.5 \mathrm{~kg}$ of WCGF/d from approximately 7 to 10 mo of age (91 d; 4 pens/diet), and then were fed $1.25 \mathrm{~kg}$ of $\mathrm{SB} / \mathrm{d}$ for an additional $114 \mathrm{~d}$ (4 pens/diet). In Exp. 2, $1.25 \mathrm{~kg}$ of SB/ $\mathrm{d}$ or $1.25 \mathrm{~kg}$ of DDG/d was fed to 100 crossbred heifers for $226 \mathrm{~d}$, beginning at $6 \mathrm{mo}$ of age (4 pens/diet). At approximately $13 \mathrm{mo}$ of age, heifers were fed melengestrol acetate $(0.5 \mathrm{mg} / \mathrm{d})$ for $14 \mathrm{~d}$, followed by an i.m. injection of $\mathrm{PGF}_{2 \alpha}(25 \mathrm{mg}) 19 \mathrm{~d}$ later to synchronize
\end{abstract}

estrus. Heifers (14 mo of age) received AI for $5 \mathrm{~d}$ after $\mathrm{PGF}_{2 \alpha}$, at which time the dietary treatments were ended. Heifers were commingled while grazing on native pasture and were exposed to bulls for approximately $60 \mathrm{~d}$ beginning $10 \mathrm{~d}$ after the last day of AI. Pregnancy to AI was determined by ultrasound $45 \mathrm{~d}$ after the last day of AI. Heifers fed SB in the preliminary experiment had a lower $(P<0.05)$ synchronization rate $(81$ vs. $96 \%)$ and longer interval $(P=0.05)$ from $\mathrm{PGF}_{2 \alpha}$ to estrus ( 76.6 vs. $69.2 \mathrm{~h}$ ) compared with heifers fed WCGF. In Exp. 1, the age at which the heifers were begun on SB diets did not alter $(P>0.10)$ the synchronization rate $(79 \%)$ or timing of estrus after $\mathrm{PGF}_{2 \alpha}(77.8 \mathrm{~h})$. In Exp. 2, the synchronization rate $(86 \%)$ and timing of estrus after $\mathrm{PGF}_{2 \alpha}(69.3 \mathrm{~h})$ did not differ $(P>0.10)$ because of diet. No differences $(P>$ 0.10 ) were due to diet for AI conception rates (overall mean for each experiment: $76.5,60$, and $68.5 \%$ ), percentage of all heifers becoming pregnant to $\mathrm{AI}(67,46$, and 59\%), or final pregnancy rates (92, 90, and 90\%) in the preliminary experiment, Exp. 1, or Exp. 2, respectively. In summary, SB, DDG, and WCGF can be used as sources of protein in heifer development diets at the inclusion rates used in these studies.

Key words: fertility, heifer development, protein supplement

(C2008 American Society of Animal Science. All rights reserved.

J. Anim. Sci. 2008. 86:476-482

doi:10.2527/jas.2007-0207

\section{INTRODUCTION}

Development of replacement heifers at growth rates sufficient to ensure puberty before breeding is critical

\footnotetext{
${ }^{1} \mathrm{~A}$ contribution of the University of Nebraska Agricultural Research Division, supported in part by funds provided through the Hatch Act. Mention of a proprietary product does not constitute a guarantee or warranty of the product by USDA or the authors and does not imply its approval to the exclusion of other products that may be also suitable.

${ }^{2}$ The authors wish to acknowledge the financial support of the Nebraska Soybean Board, and IVX Animal Health, St. Joseph, MO, for donation of products.
}

for efficient beef cattle production. Supplementation of low- or medium-quality roughage diets with high-energy sources of protein can provide sufficient nutrients to support adequate development for successful reproductive function and can be economical (Albro et al., 1993). High-fat protein supplements have positive effects on reproductive performance that appear to be independent of their energy contribution (Williams and

\footnotetext{
${ }^{3}$ Corresponding author: rfunston2@unl.edu

Received April 9, 2007.

Accepted October 6, 2007.
} 
Stanko, 1999). However, the benefits of dietary fat in heifer development diets may be limited to circumstances in which high-fat sources of protein are priced comparably to other supplements (Funston, 2004). Whole soybeans (SB) are an economical, nutrient-dense feed ingredient (90\% TDN, $40 \%$ CP, $18 \%$ fat, DM basis; NRC, 2000), which, in diets of weaned calves fed lowquality forage, has resulted in similar $\mathrm{ADG}$, intake, and digestibility compared with calves receiving extruded SB or SB meal (Albro et al., 1993). Other sources of protein come from the corn-milling industry as by-products, such as wet corn gluten feed (WCGF; 80\% TDN, $24 \%$ CP, $4 \%$ fat, DM basis; NRC, 2000) and corn dried distillers grains (DDG; $88 \%$ TDN, 30\% CP, 11\% fat, DM basis; NRC, 2000). Because of the annual cyclic nature of the market value of these diet ingredients, the opportunity may exist to substitute these ingredients for other sources of protein when market conditions are favorable. The marked difference in fat content among these ingredients provides the opportunity to explore potential benefits of increased fat levels in heifer development diets.

The objectives of this study were to compare puberty status before synchronization of estrus, response to synchronization, and $\mathrm{AI}$ and final pregnancy rates in heifers developed on diets containing SB and either WCGF or DDG, which were formulated to be similar in energy and $\mathrm{CP}$.

\section{MATERIALS AND METHODS}

The University of Nebraska-Lincoln Animal Care and Use Committee approved the procedures and facilities for this experiment.

Three experiments were conducted over 3 yr (1 experiment/yr) to evaluate the reproductive response and rate of growth in crossbred (Angus $\times$ Simmental) springborn beef heifers developed with whole raw SB, WCGF, or DDG as part of a total mixed diet containing corn silage, wheat straw, brome grass hay, and a mineral supplement. For each experiment, heifers were allotted by BW and randomly assigned to 1 of 2 dietary treatments (Table 1). Diets within each experiment were similar in energy (TDN basis) and CP content (Table 1 ), and were formulated to achieve target weights of $400 \mathrm{~kg}$ (approximately 65\% of mature BW) at the time of AI, based on BW at treatment initiation.

\section{Preliminary Experiment}

A preliminary experiment was performed to measure the performance and reproductive response of crossbred beef heifers fed whole raw SB or WCGF as part of a total mixed diet. Spring-born heifers $(\mathrm{n}=104)$ weighed $300 \mathrm{~kg}(\mathrm{SD}=30.9$ ) and averaged 10 mo of age when the treatment diets were initiated. Heifers were divided into 2 separate pens and fed a DM equivalent of either $1.25 \mathrm{~kg}$ of $\mathrm{SB} / \mathrm{d}$ or $2.0 \mathrm{~kg}$ of WCGF/d per heifer as a protein source in a total mixed diet containing corn silage, wheat straw, brome grass hay, and a mineral supplement. Diets were offered once daily until completion of a 5-d AI protocol, which began on d 111 when the heifers were estrus synchronized, as described below. Heifers were maintained on their respective dietary treatments throughout the AI period. The authors acknowledge that the diets were not replicated in multiple pens, and to minimize the possible effects of pen, heifers were rotated between pens after each blood sample collection and BW measurement (described below). Data obtained from this study were therefore explored more fully in Exp. 1, in which treatments were applied to multiple pens.

Two blood samples were collected $7 \mathrm{~d}$ apart before the dietary treatments began $(\mathrm{d}-7$ and 0 of the treatment period) and at the midpoint of the treatment period (d 51 and 58). Serum from these samples was used to determine circulating concentrations of progesterone as an indication of pubertal status. Blood samples were stored at $4^{\circ} \mathrm{C}$ until serum was obtained by centrifugation within $24 \mathrm{~h}$ of collection. Serum samples were stored at $-20^{\circ} \mathrm{C}$ for subsequent analysis. Heifers with serum progesterone concentrations $\geq 1 \mathrm{ng} / \mathrm{mL}$ were considered to be pubertal.

Heifers were weighed, without prior access to food or water, at the time of each blood collection (d -7, 0, 51, and 58) and on the day of the $\mathrm{PGF}_{2 \alpha}$ injection (d 111; described below). Beginning at d 79, heifers were synchronized by feeding melengestrol acetate (MGA; 0.5 $\mathrm{mg} / \mathrm{d}$, Pfizer Animal Health, New York, NY) for $14 \mathrm{~d}$, followed by an injection of $\mathrm{PGF}_{2 \alpha}$ (25 mg i.m. ProstaMate, IVX Animal Health, St. Joseph, MO) 19 d later (d 111). Heifers were observed for estrous activity continuously during daylight for $5 \mathrm{~d}$ after the $\mathrm{PGF}_{2 \alpha}$ injection. Heifers detected in estrus before 1200 were inseminated in the evening, and those observed in estrus after 1200 were inseminated the following morning. Heifers were randomly subjected to AI with semen from 1 of 2 proven sires by 1 of 3 technicians. Heifers not detected in estrus were placed with bulls immediately after the AI period. Ten days after the last AI, all heifers were placed on native pasture with bulls for approximately $60 \mathrm{~d}$ (1 bull:33 heifers). Pregnancy to AI was diagnosed by transrectal ultrasonography approximately $45 \mathrm{~d}$ after the last AI date. Final pregnancy rates were determined approximately $45 \mathrm{~d}$ after the bulls were removed. Body weights were determined at the time of each transrectal ultrasonography.

\section{Exp. 1}

In Exp. 1, 100 crossbred, spring-born heifers weighing $253 \mathrm{~kg}(\mathrm{SD}=26)$ and approximately $7 \mathrm{mo}$ of age were randomly assigned to 1 of 2 treatment groups and allotted by BW to 1 of 4 pens per treatment, with 12 or 13 heifers per pen. Heifers were fed a DM equivalent of $1.25 \mathrm{~kg}$ of SB/d or $2.5 \mathrm{~kg}$ of WCGF/d per heifer for $91 \mathrm{~d}$ (Table 1). A 5-d step-up period was included in the SB-fed group, with incremental increases of 0.25 
Table 1. Ingredients and composition of soybean (SB) and wet corn gluten feed (WCGF) diets fed in the preliminary experiment, early- and late-supplemented SB (SB and WCGF/SB) diets fed in Exp. 1, or SB and dried distillers grain (DDG) diets fed in Exp. 2

\begin{tabular}{|c|c|c|c|c|c|c|c|}
\hline Item & \multicolumn{2}{|c|}{ Preliminary experiment } & \multicolumn{3}{|c|}{ Experiment 1} & \multicolumn{2}{|c|}{ Experiment 2} \\
\hline \multicolumn{8}{|l|}{ Ingredient, $\%$ of $\mathrm{DM}$} \\
\hline Corn silage & 32.7 & 30.1 & 23.0 & 16.4 & 20.5 & 28.0 & 24.4 \\
\hline Wheat straw & 47.8 & 21.3 & 12.6 & 11.9 & 22.3 & 24.2 & 21.8 \\
\hline Brome grass hay & - & 31.9 & 31.4 & 35.7 & 27.9 & 27.0 & 32.9 \\
\hline Soybeans & 15.9 & - & 19.1 & - & 16.9 & 16.7 & - \\
\hline Corn & - & - & 9.4 & - & 8.4 & - & - \\
\hline Supplement ${ }^{4}$ & 3.5 & 3.5 & 4.5 & 4.3 & 4.0 & 4.1 & 4.1 \\
\hline \multicolumn{8}{|c|}{ Formulated nutrient composition, $\%$ of DM } \\
\hline $\mathrm{CP}$ & 11.2 & 10.8 & 13.5 & 13.1 & 12.5 & 12.2 & 11.3 \\
\hline TDN & 65.3 & 64.2 & 67.5 & 65.3 & 65.0 & 64.4 & 65.5 \\
\hline Fat & 5.0 & 2.3 & 5.3 & 2.5 & 5.2 & 5.1 & 3.6 \\
\hline
\end{tabular}

${ }^{1}$ Diet fed to SB-supplemented heifers from November 6, 2004, through January 31, 2005, after the 5-d step-up period that began November $1,2004$.

${ }^{2}$ Diet fed to WCGF/SB-supplemented heifers from November 1, 2004, through January 31, 2005.

${ }^{3}$ Diet fed to both SB- and WCGF/SB-supplemented heifers from February 5, 2005, through May 30, 2005; the 5-d step-up period for WCGF/ SB-supplemented heifers began January 31, 2005.

${ }^{4}$ Feather meal, calcium carbonate, ground corn, blood meal, salt, TM mix, and vitamin mix, formulated to provide 200 mg of Bovatec (Alpharma, Fort Lee, NJ) per animal daily.

$\mathrm{kg}$ of SB (DM) per heifer daily, such that $1.25 \mathrm{~kg}$ of SB/ $\mathrm{d}$ was fed on treatment $\mathrm{d} 6$ through d 91 . After $91 \mathrm{~d}$, when heifers were approximately 10 mo of age and 335 $\mathrm{kg}(\mathrm{SD}=30)$ of BW, WCGF was replaced with SB so that the heifers in both treatments were fed a DM equivalent of $1.25 \mathrm{~kg}$ of SB/d for an additional $114 \mathrm{~d}$. Heifers previously fed WCGF were fed incremental levels of SB, as previously described, from d 92 to 96 of the treatment. Total durations of feeding the SB diets in Exp. 1 were $114 \mathrm{~d}$ (WCGF/SB) and $211 \mathrm{~d}$ (SB only), respectively. Heifers were maintained on their respective dietary treatments throughout the AI period.

Two blood samples were collected $10 \mathrm{~d}$ apart before dietary treatments began $(\mathrm{d}-10$ and 0 of the treatment period) and before synchronization (as described below; d 165 and 175), when the heifers were approximately 12.5 and 13 mo of age. Serum was obtained from the blood samples as described for the preliminary experiment, and progesterone concentrations were used as an indicator of pubertal status, as described previously.

Body weights were determined at the time of blood collection and at the end of the treatment period. Beginning at approximately 12 mo of age (d 176 of the treatment period), heifers were synchronized by feeding MGA $(0.5 \mathrm{mg} / \mathrm{d})$ for $14 \mathrm{~d}$, followed by an injection of $\mathrm{PGF}_{2 \alpha}$ (25 mg i.m. ProstaMate, IVX Animal Health) 19 d later. Heifers were observed for estrous activity and received $\mathrm{AI}$ as described in the preliminary experiment. Heifers were randomly inseminated with semen from 1 of 3 proven sires by 1 of 3 technicians. Heifers not detected in estrus were placed with bulls immediately after the synchronization period. Ten days after the last AI, all heifers were placed on native pasture with bulls for approximately $60 \mathrm{~d}$ (1 bull:50 heifers). Pregnancy diagnosis was determined as described for the preliminary experiment. Body weights were determined at the time of each transrectal ultrasonography.

\section{Exp. 2}

For Exp. 2, 100 heifers, weighing $229 \mathrm{~kg}(\mathrm{SD}=21)$ and approximately 6 mo of age, were randomly assigned to 1 of 2 treatment groups and allotted by BW to 1 of 4 pens per treatment, with 12 or 13 heifers per pen. Heifers were fed diets containing a DM equivalent of $1.25 \mathrm{~kg}$ of SB/d or $1.25 \mathrm{~kg}$ of DDG/d per heifer for 216 d after a 5-d step-up period, as described for Exp. 1. Heifers were maintained on their respective dietary treatments throughout the AI period.

Two blood samples were collected $10 \mathrm{~d}$ apart before dietary treatments began $(\mathrm{d}-10$ and 0 of the treatment period) and before synchronization (as described below; d 174 and 184), when the heifers were approximately 12.5 and 13 mo of age. Serum was obtained from the blood samples as described for the preliminary experiment, and progesterone concentrations were used as an indicator of pubertal status, as described previously.

Body weights were determined at the time of blood collection and at the end of the treatment period. Beginning at approximately 12 mo of age (d 185), the heifers were synchronized and received $\mathrm{AI}$ as described in the preliminary experiment. Heifers were randomly inseminated with semen from 1 of 3 proven sires by 1 of 4 technicians. Heifers not detected in estrus were placed with bulls immediately after the synchronization period. Ten days after the last AI, all heifers were placed 
on native pasture with bulls for approximately $60 \mathrm{~d}$ (1 bull:50 heifers). Pregnancy diagnosis was determined as described for the preliminary experiment. Body weights were determined at the time of each transrectal ultrasonography.

\section{Laboratory Analysis}

Diets containing SB had greater dietary fat compared with the WCGF and DDG diets (Table 1). In the preliminary study, the SB-supplemented diet contained $2.7 \%$ more fat than the WCGF-supplemented diet. The nutrient content (DM basis) of the protein sources fed in the preliminary experiment was $93 \% \mathrm{TDN}, 38 \% \mathrm{CP}$, and $20 \%$ fat for SB; and $82 \%$ TDN, $24 \% \mathrm{CP}$, and $4 \%$ fat for WCGF (Ward Laboratories Inc., Kearney, NE). In the first $91 \mathrm{~d}$ of Exp. 1, the SB-supplemented diet contained $2.3 \%$ more fat than the WCGF-supplemented diet (Table 1). The nutrient content (DM basis) of the protein sources fed in Exp. 1 was 92\% TDN, 37\% CP, and 20\% fat for SB; and $82 \% \mathrm{TDN}, 24 \% \mathrm{CP}$, and $4 \%$ fat for WCGF (Ward Laboratories Inc.). In Exp. 2, the SB-supplemented diet contained $1.7 \%$ more fat than the DDGsupplemented diet. The nutrient content (DM basis) of the protein sources fed in Exp. 2 was 92\% TDN, 37\% $\mathrm{CP}$, and $21 \%$ fat for SB; and $108 \% \mathrm{TDN}, 30 \% \mathrm{CP}$, and $11 \%$ fat for DDG (Ward Laboratories Inc.). Feed samples were collected every $30 \mathrm{~d}$ and were sent to a commercial laboratory (Ward Laboratories Inc.) for analysis. Dietary TDN was determined by using the formula 93.5 - (ADF × 1.03).

Concentrations of progesterone in serum were determined without extraction by using a solid-phase RIA kit (Coat-A-Count; Diagnostic Products Corp., Los Angeles, CA), as described previously (Stewart et al., 1996), for the preliminary experiment and Exp. 2, or by an RIA consisting of primary antibody and $\mathrm{I}^{125}$-labeled progesterone from ICN Pharmaceuticals Inc. (Costa Mesa, CA; Roberts et al., 2005) for Exp. 1. Intraassay and interassay CV did not exceed 8 and $15 \%$, respectively. Assay sensitivity was approximately $0.04 \mathrm{ng} / \mathrm{mL}$ for both assays.

\section{Statistical Analysis}

Differences in pubertal status, synchronization response, conception, and pregnancy rates were analyzed with animal as the experimental unit by $\chi^{2}$ analysis by PROC GENMOD (SAS Inst. Inc., Cary, NC), using an initial model including the fixed effects of treatment and pen within treatment. In addition, sire and technician were included in the model for conception and pregnancy rates for all experiments. Pen within treatment and technician were removed from the model statement for Exp. 1 and 2, and sire was removed from the model statement for Exp. 1, because these factors were not significant $(P>0.10)$. Data were then reanalyzed with only treatment (Exp. 1) or treatment and sire (Exp. 2) remaining in the model. Means for bino- mial data were evaluated by generating frequency tables using PROC FREQ of SAS. Effects of diets on BW of heifers from Exp. 1 and 2 were analyzed by the MIXED procedure of SAS for repeated-measures ANOVA, with the compound symmetry covariance structure and using a model that included the main effect of diet, day on which BW was measured, the interaction of these effects, and pen within treatment as a repeated measure. Effects of diets on ADG for different periods of each experiment and the timing of estrus were analyzed by using the GLM procedure of SAS, with heifer within treatment (preliminary experiment) or pen within treatment (Exp. 1 and 2) as the error term.

\section{RESULTS AND DISCUSSION}

\section{Preliminary Experiment}

Pubertal status was not different $(P \geq 0.23)$ between treatments at any time measured. At the initiation of treatments, when heifers were approximately 10 mo of age, $82 \%$ were pubertal. At the midpoint of the feeding period, when heifers were approximately 12 mo old, $98 \%$ had reached puberty. A greater $(P=0.01)$ percentage of heifers on the WCGF diet (96\%) exhibited estrus during the 5 -d breeding period after $\mathrm{PGF}_{2 \alpha}$ than heifers fed SB (81\%; Table 2). The average interval from $\mathrm{PGF}_{2 \alpha}$ to estrus for heifers exhibiting estrus during the synchronization period was greater $(P=0.05)$ for heifers fed SB than those fed WCGF (76.6 vs. $69.2 \mathrm{~h}$; Table 2). Diet did not affect $(P \geq 0.50)$ the percentage of heifers detected in estrus that became pregnant by AI (AI conception rate), the percentage of all heifers pregnant by AI (AI pregnancy rate), or the percentage of heifers pregnant by AI or natural service (final pregnancy rate; Table 2).

Even though heifers were managed together after AI, heifers from the SB group gained more $(P<0.01)$ weight from the $\mathrm{PGF}_{2 \alpha}$ injection to first ultrasound and were heavier $(P=0.02)$ at the time of first ultrasound than heifers in the WCGF group. This difference in BW tended $(P=0.06)$ to persist out to $90 \mathrm{~d}$ after AI, but $\mathrm{ADG}$ for the period between 45 and $90 \mathrm{~d}$ after AI did not differ $(P=0.30)$ between groups (Table 3$)$. Because of the difference $(P<0.01)$ in $\mathrm{ADG}$ from $\mathrm{PGF}_{2 \alpha}$ injection to $45 \mathrm{~d}$ after AI, the rate of gain over the entire period between synchronization and $90 \mathrm{~d}$ after $\mathrm{AI}$ was greater $(P<0.01)$ in the SB group (Table 3$)$.

The reason for the difference in synchronization rate, time of estrus, and posttreatment ADG between groups is not known. The majority of heifers in the preliminary study were pubertal (82\%) when treatment began. Therefore, Exp. 1 was conducted to evaluate whether the age or duration when SB were fed influenced the reproductive response.

\section{Exp. 1}

As observed in the preliminary experiment, dietary treatments in Exp. 1 did not affect $(P \geq 0.54)$ the propor- 
Table 2. Synchronization rate (\%), average time of synchronized estrus, and pregnancy rates for heifers fed whole soybean (SB) or wet corn gluten feed (WCGF) diets in the preliminary experiment, SB beginning early (SB) or late (WCGF/SB) in Exp. 1, or SB and dried distillers grain (DDG) diets in Exp. 2

\begin{tabular}{|c|c|c|c|c|c|c|c|c|c|}
\hline \multirow[b]{2}{*}{ Trait } & \multicolumn{3}{|c|}{ Preliminary experiment } & \multicolumn{3}{|c|}{ Experiment 1} & \multicolumn{3}{|c|}{ Experiment 2} \\
\hline & SB & WCGF & SEM & SB & WCGF/SB & SEM & SB & DDG & SEM \\
\hline Heifers, $n$ & 52 & 52 & & 50 & 50 & & 50 & 50 & \\
\hline Synchronization rate, ${ }^{1} \%$ & $81^{\mathrm{a}}$ & $96^{\mathrm{b}}$ & 0.30 & 77 & 80 & 0.20 & 84 & 88 & 0.20 \\
\hline Estrus, ${ }^{2} \mathrm{~h}$ & $76.6^{\mathrm{a}}$ & $69.2^{\mathrm{b}}$ & 2.59 & 79.8 & 75.9 & 3.34 & 68.9 & 69.8 & 2.18 \\
\hline $\mathrm{AI}$ conception rate, $\%$ & 81 & 72 & 0.48 & 62 & 58 & 0.47 & 69 & 68 & 0.47 \\
\hline AI pregnancy rate, $\%$ & 65 & 69 & 0.42 & 46 & 46 & 0.40 & 58 & 60 & 0.41 \\
\hline Final pregnancy rate, $\%$ & 90 & 94 & 0.79 & 94 & 86 & 0.72 & 88 & 92 & 0.68 \\
\hline
\end{tabular}

a,b Treatment means within a row within an experiment that do not have common superscripts differ $(P$ $\leq 0.05$ ).

${ }^{1}$ Percentage observed in estrus during the 5-d period after $\mathrm{PGF}_{2 \alpha}$ injection.

${ }^{2}$ Average time (hours) after $\mathrm{PGF}_{2 \alpha}$ injection at which estrus was observed.

tion of heifers that were pubertal at any time measured. At approximately 6 mo of age, when treatment was initiated, 14 and $10 \%$ of heifers were pubertal in the SB and WCGF groups, respectively, resulting in a puberty rate of $12 \%$ across the 2 treatments. At 10 mo of age, when heifers in the WCGF group were started on SB, $62 \%$ of heifers in the SB group were pubertal and 56\% of heifers in the WCGF group were pubertal, with an overall puberty rate of 59\%. Ninety-eight percent of all heifers had reached puberty by the beginning of MGA administration. The percentage of heifers responding to synchronization was not different $(P=0.48)$ between treatments (Table 2). The average time from $\mathrm{PGF}_{2 \alpha}$ injection to estrus $(77.8 \mathrm{~h})$ was also similar $(P=0.40)$ between treatments. The conception to AI, AI pregnancy, and final pregnancy rates were not different $(P$ $\geq 0.18$ ) between treatments (overall means of 60,46 , and $90 \%$, respectively; Table 2). The synchronization rate and time of estrus observed for both treatments in Exp. 1 were similar to those of heifers fed SB in the preliminary experiment. These data are in agreement with Howlett et al. (2003), who found no differences in pubertal percentage at the beginning of the breeding season or first-service conception rates when beef heifers were developed with corn and soybean meal, whole cottonseed, whole soybeans, or pelleted soyhull supplements. Funston et al. (2002) found no benefit in estrous response or pregnancy rate in heifers fed whole sunflower seeds 30 or $60 \mathrm{~d}$ before AI compared with a diet similar in CP and TDN. In contrast, there have been reports of increased reproductive performance when vegetable oils or oilseeds were fed to prepubertal heifers

Table 3. Body weight $(\mathrm{kg})$ and ADG $(\mathrm{kg} / \mathrm{d})$ of heifers developed on diets containing either whole soybeans (SB) or wet corn gluten feed (WCGF; preliminary experiment.); SB beginning early (SB) or late (WCGF/SB; Exp. 1) in the postweaning period; and SB or dried distillers grains (DDG; Exp. 2)

\begin{tabular}{|c|c|c|c|c|c|c|c|c|}
\hline Item & \multicolumn{2}{|c|}{ Preliminary experiment } & \multicolumn{3}{|c|}{ Experiment 1} & \multicolumn{3}{|c|}{ Experiment 2} \\
\hline Heifers, $\mathrm{n}$ & 52 & 52 & 50 & 50 & & 50 & 50 & \\
\hline Length of dietary treatment, $\mathrm{d}$ & 110 & 110 & 205 & $205^{1}$ & & 226 & 226 & \\
\hline Initial $\mathrm{BW},{ }^{2} \mathrm{~kg}$ & 299 & 300 & 253 & 253 & 3.52 & 230 & 229 & 3.00 \\
\hline $\mathrm{BW}$ at $13 \mathrm{mo}$ old,$^{3} \mathrm{~kg}$ & 350 & 343 & $379^{\mathrm{a}}$ & $394^{\mathrm{c}}$ & 4.84 & 369 & 380 & 3.95 \\
\hline BW $45 \mathrm{~d}$ after end of treatment, ${ }^{5} \mathrm{~kg}$ & $383^{\mathrm{a}}$ & $368^{\mathrm{c}}$ & $389^{\mathrm{a}}$ & $403^{c}$ & 4.48 & 383 & 395 & 4.01 \\
\hline $\mathrm{ADG}$ for $45-\mathrm{d}$ period after treatment, $\mathrm{kg}$ & $0.03^{\mathrm{a}}$ & $-0.27^{\mathrm{d}}$ & $0.13^{\mathrm{a}}$ & $-0.31^{\mathrm{d}}$ & 0.04 & 0.15 & 0.11 & 0.04 \\
\hline BW $90 \mathrm{~d}$ after end of treatment, ${ }^{5} \mathrm{~kg}$ & $415^{\mathrm{a}}$ & $402^{\mathrm{b}}$ & $427^{\mathrm{a}}$ & $440^{\mathrm{c}}$ & 4.61 & 442 & 451 & 4.37 \\
\hline ADG from 45 to $90 \mathrm{~d}$ after treatment, $\mathrm{kg}$ & 0.66 & 0.72 & 0.60 & 0.58 & 0.02 & 0.85 & 0.80 & 0.05 \\
\hline ADG for $90-\mathrm{d}$ period after treatment, $\mathrm{kg}$ & $0.35^{\mathrm{a}}$ & $0.24^{\mathrm{d}}$ & $0.28^{\mathrm{a}}$ & $0.18^{d}$ & 0.02 & 0.56 & 0.51 & 0.02 \\
\hline
\end{tabular}

${ }^{\mathrm{a}, \mathrm{b}}$ Treatment means within a row within an experiment that do not have common superscripts tended to differ $(P<0.10)$.

a,cTreatment means within a row within an experiment that do not have common superscripts differ $(P<0.05)$.

${ }^{\text {a,d }}$ Treatment means within a row within an experiment that do not have common superscripts differ $(P \leq 0.01)$.

${ }^{1}$ Heifers were fed a diet containing WCGF for $114 \mathrm{~d}$ from 7 to 10 mo of age, and were switched to SB from d 115 to 205 .

${ }^{2}$ Average of 2 weights taken at the beginning of the experimental period.

${ }^{3}$ Taken at the beginning of melengestrol acetate administration; not statistically evaluated in the preliminary experiment.

${ }^{4}$ Taken at the time of $\mathrm{PGF}_{2 \alpha}$ injection $5 \mathrm{~d}$ prior to the end of the dietary treatment; not statistically evaluated in the preliminary experiment.

${ }^{5}$ Taken at the time of ultrasound pregnancy diagnosis 45 and $90 \mathrm{~d}$ after $\mathrm{PGF}_{2 \alpha}$ injection. 
(Lammoglia et al., 2000; Whitney et al., 2000). However, reproductive responses to feeding vegetable oil or oilseeds have been inconsistent in other studies. Whitney et al. (2000) reported a decrease in days to conception in 1 of 2 experiments using soybean oil as a lipid source, and Lammoglia et al. (2000) reported a breed $\times$ diet interaction for the percentage of heifers attaining puberty by the beginning of the breeding season: a decrease in Piedmontese-sired heifers, an increase in Limousin-sired heifers, and no effect on Hereford-sired heifers fed cracked safflower seeds.

Heifer BW tended to be influenced $(P=0.10)$ by the interaction of time and treatment (Table 3). There was no difference $(P>0.10)$ in BW $(316 \mathrm{~kg})$ or ADG $(0.89$ $\mathrm{kg} / \mathrm{d}$ ) after the first $91 \mathrm{~d}$ heifers were fed different diets. Although both groups were fed SB for the last $114 \mathrm{~d}$ of the feeding period, heifers fed WCGF during the first $91 \mathrm{~d}$ were heavier $(P=0.01)$ at approximately $13 \mathrm{mo}$ of age when MGA feeding was initiated (d 168 of the experiment; Table 3). Heifers in the WCGF/SB group remained heavier $(P<0.01)$ than heifers in the SB-only group for the remainder of the study (Table 3). Thus, ADG from d 168 to 210, when both groups received SB, was greater $(P<0.01)$ in heifers fed WCGF during the early development period. The reason for this difference in $\mathrm{ADG}$ is not clear. Heifers in the WCGF/SB group experienced a greater $(P<0.01)$ loss of BW during the period from $\mathrm{AI}$ to $45 \mathrm{~d}$ after $\mathrm{AI}$ than heifers in the SB-only group. No difference $(P=0.22)$ in ADG was observed from 45 to $90 \mathrm{~d}$ after AI. Average daily gain from AI to $90 \mathrm{~d}$ after AI was greater $(P=0.01)$ in heifers fed SB throughout the treatment period than in heifers fed SB for the last $114 \mathrm{~d}$ (Table 3). Differences in growth rates observed in both Exp. 1 and the preliminary experiment occurred after differences in dietary treatments had ended and heifers were placed on similar diets (i.e., SB in the later part of Exp. 1) or on pasture (Exp. 1 and the preliminary experiment). In a review of dietary fats as reproductive nutraceuticals, feeding unsaturated vegetable oil sources of fat at rates $>5 \%$ of total DMI was reported to markedly reduce fiber digestibility and reduce DMI in ruminants (Williams and Stanko, 1999). However, certain types of fat-containing feedstuffs have been fed at levels $>5 \%$ without negative effects, possibly because ruminal metabolism of the oil is slowed by the fibrous seed coat, and a portion of the fat actually bypasses the rumen intact (Coppock and Wilks, 1991). Funston et al. (2002) reported decreased ADG in heifers fed whole sunflower seeds compared with a control diet similar in energy and CP; dietary fat was $6.4 \%$ and may have negatively influenced fiber digestion. Howlett et al. (2003) reported a decrease in ruminal NDF digestibility when either cottonseed or soybeans were added to the diet compared with protein sources (soyhulls and soybean meal) lower in fat content, which did not support the view that feeding whole oilseeds may partially protect fatty acids from ruminal metabolism. It is possible that the oil from soybeans inhibited fiber digestion in the current study and resulted in a decrease in ADG during the feeding period and that the increase in ADG on pasture was a result of compensatory gain. Because fat content was a major difference in the composition of the SB and WCGF diets used in these experiments, these results provide a precedent for the need for future research to determine whether diets high in fat may have some beneficial effect associated with adaptation of heifers to a forage diet or whether this is a compensatory response in heifers previously fed a diet high in fat (i.e., at or above $5 \%$ of DMI).

Experiment 2 was conducted to evaluate DDG in heifer development diets. Dried distillers grains were selected for Exp. 2 in place of WCGF because of the greater fat content in DDG [11 vs. $4 \%$ fat (DM) for DDG and WCGF, respectively; NRC, 2000].

\section{Exp. 2}

Treatments did not affect $(P \geq 0.24)$ the cycling status at any time measured. At the time when treatments were initiated (approximately 6 mo of age), 18\% of heifers were pubertal. At MGA administration, when heifers were approximately 13 mo of age, $99 \%$ were pubertal. There was no difference between groups in synchronization rate $(86 \% ; P=0.60)$ or average time of estrus after $\mathrm{PGF}_{2 \alpha}(69.3 \mathrm{~h} ; P=0.75$; Table 2). These results are in contrast to the preliminary experiment, where the synchronization response and time to estrus were different between treatment groups. Synchronization responses in Exp. 2 were intermediate between those of SB-fed heifers in Exp. 1 and the preliminary experiment and the WCGF-fed heifers in the preliminary experiment, whereas the time to estrus in SB-fed heifers from Exp. 2 was earlier than that observed in SB-fed heifers from Exp. 1 and the preliminary experiment, thereby preventing any speculation on the impact of variations in fat content on these responses. No differences $(P \geq 0.50)$ were due to diet for AI conception, AI pregnancy, or final pregnancy rates (Table 2). Sire influenced $(P=0.10)$ conception to AI, with $\mathrm{AI}$ conception rates of 79,55 , and $75 \%$ for sires $\mathrm{A}, \mathrm{B}$, and $\mathrm{C}$, respectively. Martin et al. (2007) used DDG as a supplement in beef heifer diets to evaluate the effects of feeding excess undegradable intake protein on the reproductive response. A control supplement consisting of dried corn gluten feed, corn germ, and urea was formulated to be equal in fat, $\mathrm{CP}$, and energy. Feeding DDG at $0.59 \%$ of BW (DM basis) during development did not affect the age at puberty but improved the AI conception and pregnancy rates. Apparently, something other than fat had a positive effect on reproduction in the study by Martin et al. (2007).

Heifer BW was not influenced by $\operatorname{diet}(P=0.24)$ or the time $\times$ treatment interaction $(P=0.51)$. However, ADG over the 226-d feeding period was greater $(P=$ 0.03) for DDG-fed heifers than SB-fed heifers (Table 3 ). Average daily gain for the period after the dietary treatment did not differ between treatment groups ( $P$ 
$\geq 0.28$ ). The difference in ADG during the feeding period is consistent with the hypothesis put forth from Exp. 1 that oil from the soybeans may be inhibiting fiber digestion. However, a compensatory response following cessation of SB feeding was not evident when compared with DDG (numerically greater ADG in heifers previously fed $\mathrm{SB}$, but not significant).

In summary, SB, DDG, and WCGF can be used as protein sources for heifer development diets when fed at the rates used in these studies. Developing heifers on whole SB had enhanced BW gain after the developmental period when compared with heifers fed WCGF, indicating that SB may be advantageous for the adaptation of heifers onto pasture. However, ADG was not different between heifers developed on SB or DDG during the grazing period. Among the heifers fed SB and responding to estrous synchronization in the preliminary experiment, the interval from $\mathrm{PGF}_{2 \alpha}$ to estrus $(76.6 \mathrm{~h})$ was prolonged compared with heifers fed diets containing WCGF $(69.2 \mathrm{~h})$. Studies are limited on the use of fat supplements in replacement heifer diets; however, these studies agree with others demonstrating no beneficial or detrimental effect of supplementing fat from a variety of sources at inclusion rates of 2 to $5 \%$ of DM (Funston et al., 2002; Garcia et al., 2003; Howlett et al., 2003).

\section{LITERATURE CITED}

Albro, J. D., D. W. Weber, and T. DelCurto. 1993. Comparison of whole, raw soybeans, extruded soybeans, or soybean meal and barley on digestive characteristics and performance of weaned beef steers consuming mature grass hay. J. Anim. Sci. 71:26-32.

Coppock, C. E., and D. L. Wilks. 1991. Supplemental fat in highenergy rations for lactating cows: Effects on intake, digestion, milk yield, and composition. J. Anim. Sci. 69:3826-3837.
Funston, R. N. 2004. Fat supplementation and reproduction in beef females. J. Anim. Sci. 82:E154-E161.

Funston, R. N., T. W. Geary, R. P. Ansotegui, R. J. Lipsey, and J. A. Paterson. 2002. Supplementation with whole sunflower seeds before artificial insemination in beef heifers. Prof. Anim. Sci. 18:254-257.

Garcia, M. R., M. Amstalden, C. D. Morrison, D. H. Keisler, and G. L. Williams. 2003. Age at puberty, total fat and conjugated linoleic acid content of carcass, and circulating metabolic hormones in beef heifers fed a diet high in linoleic acid beginning at four months of age. J. Anim. Sci. 81:261-268.

Howlett, C. M., E. S. Vanzant, L. H. Anderson, W. R. Burris, B. G. Fieser, and R. F. Bapst. 2003. Effect of supplemental nutrient source on heifer growth and reproductive performance and on utilization of corn silage-based diets by beef steers. J. Anim. Sci. 81:2367-2378.

Lammoglia, M. A., R. A. Bellows, E. E. Grings, J. W. Bergman, S. E. Bellows, R. E. Short, D. M. Hallford, and R. D. Randel. 2000. Effects of dietary fat and sire breed on puberty, weight, and reproductive traits of F1 beef heifers. J. Anim. Sci. 78:2244-2252.

Martin, J. L., A. S. Cupp, R. J. Rasby, Z. C. Hall, and R. N. Funston. 2007. Utilization of dried distillers grains for developing beef heifers. J. Anim. Sci. 85:2298-2303.

NRC. 2000. Nutrient Requirements of Beef Cattle. 7th ed. Natl. Acad. Press, Washington, DC.

Roberts, A. J., J. Klindt, and T. G. Jenkins. 2005. Effects of varying energy intake and sire breed on resumption of estrus, insulinlike growth factor-1 and growth hormone in mature crossbred cows. J. Anim. Sci. 83:1705-1714.

Stewart, R. E., L. J. Spicer, T. D. Hamilton, B. E. Keefer, L. J. Dawson, G. L. Morgan, and S. E. Echternkamp. 1996. Levels of insulinlike growth factor (IGF) binding proteins, luteinizing hormone and IGF-I receptors, and steroids in dominant follicles during the first follicular wave in cattle exhibiting regular estrous cycles. Endocrinology 137:2842-2850.

Whitney, W. B., B. W. Hess, L. A. Burgwald-Balstad, J. L. Sayer, C. M. Tsopito, C. T. Talbott, and D. M. Hallford. 2000. Effects of supplemental soybean oil level on in vitro digestion and performance of prepubertal beef heifers. J. Anim. Sci. 78:504-514.

Williams, G. L., and R. L. Stanko. 1999. Dietary fats as reproductive nutraceuticals in beef cattle. J. Anim. Sci. http://www.asas.org/ symposia/proceedings/0915.pdf Accessed Nov. 30, 2007. 